\title{
Soil liquefaction potential in Eskişehir, NW Turkey
}

\author{
H. Tosun ${ }^{1}$, E. Seyrek ${ }^{2}$, A. Orhan ${ }^{3}$, H. Savaş ${ }^{4}$, and M. Türköz ${ }^{4}$ \\ ${ }^{1}$ Eskişehir Osmangazi University, Agricultural Faculty, Eskişehir, Turkey \\ ${ }^{2}$ Dumlupınar University, Civil Engineering Department, Kütahya, Turkey \\ ${ }^{3}$ Eskişehir Osmangazi University, Geological Engineering Department, Eskişehir, Turkey \\ ${ }^{4}$ Eskişehir Osmangazi University, Civil Engineering Department, Eskişehir, Turkey
}

Received: 26 September 2010 - Revised: 30 December 2010 - Accepted: 9 February 2011 - Published: 7 April 2011

\begin{abstract}
Liquefaction is one of the critical problems in geotechnical engineering. High ground water levels and alluvial soils have a high potential risk for damage due to liquefaction, especially in seismically active regions. Eskişehir urban area, studied in this article, is situated within the second degree earthquake region on the seismic hazard zonation map of Turkey and is surrounded by Eskișehir, North Anatolian, Kütahya and Simav Fault Zones. Geotechnical investigations are carried out in two stages: field and laboratory. In the first stage, 232 boreholes in different locations were drilled and Standard Penetration Test (SPT) was performed. Test pits at 106 different locations were also excavated to support geotechnical data obtained from field tests. In the second stage, experimental studies were performed to determine the Atterberg limits and physical properties of soils. Liquefaction potential was investigated by a simplified method based on SPT. A scenario earthquake of magnitude $M=6.4$, produced by Eskişehir Fault Zone, was used in the calculations. Analyses were carried out for PGA levels at $0.19,0.30$ and $0.47 \mathrm{~g}$. The results of the analyses indicate that presence of high ground water level and alluvial soil increase the liquefaction potential with the seismic features of the region. Following the analyses, liquefaction potential maps were produced for different depth intervals and can be used effectively for development plans and risk management practices in Eskişehir.
\end{abstract}

\section{Introduction}

The liquefaction characteristic of a soil depends on several factors, such as ground acceleration, grain size distribution, soil density, thickness of the deposit and especially the position of the ground-water table. Liquefaction and ground fail-

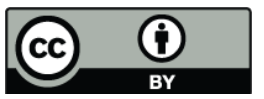

Correspondence to: A. Orhan (aorhan@ogu.edu.tr) ures are commonly associated with large earthquakes. Over the past few decades many urban areas have experienced severe damage due to liquefaction-induced soil movements (Seed and Idriss, 1967; Bardet et al., 1995; Holzer, 1998; Ansal et al., 1999; Yuan et al., 2003). Damage to structure in liquefied sediments can occur as a result of the bearing capacity failure of a foundation, lateral spreading or slope failure and differential settlement.

There are two basic approaches available to predict the liquefaction potential of soil: (1) cyclic laboratory testing on soil samples and (2) use of in-situ tests and empirical methods. The most widely used empirical method based on in-situ tests is the SPT. The framework for SPT-based assessments of liquefaction potential was first proposed by Seed and Idriss (1971). This approach evolved over the time (Seed, 1979; Seed and Idriss, 1982; Seed et al., 1985; NCEER, 1997; Youd et al., 2001; Cetin et al., 2004; Idriss and Boulanger, 2006). In the literature, liquefaction assessments of different regions are available (e.g., Chu et al., 2004; Seyrek, 2003; Ansal and Tönük, 2007; Novikova et al., 2007; Mhaske and Choudhury, 2010).

Within the scope of this paper, liquefaction potential of foundation soils in the Eskişehir settlement area has been investigated based on a simplified approach by Youd et al. (2001). The investigation comprises two stages: field work and laboratory testing. Geological and groundwater depth maps were produced and the Standard Penetration Test (SPT) was conducted. For the three peak ground accelerations $(0.19,0.37$ and $0.47 \mathrm{~g})$, with an earthquake magnitude of $M=6.4$, the liquefaction potential maps in the study area have been estimated and results of the analyses are discussed.

\section{Geology of the study area}

Eskiehir Basin is situated in northwest Turkey, at $39^{\circ} 31^{\prime}-39^{\circ} 56^{\prime} \mathrm{N}$ latitude and $30^{\circ} 17^{\prime}-30^{\circ} 45^{\prime} \mathrm{E}$ longitude; approximately $250 \mathrm{~km}$ west of Ankara (Fig. 1). The study area at the coordinates between 283.122-297.058E and

Published by Copernicus Publications on behalf of the European Geosciences Union. 


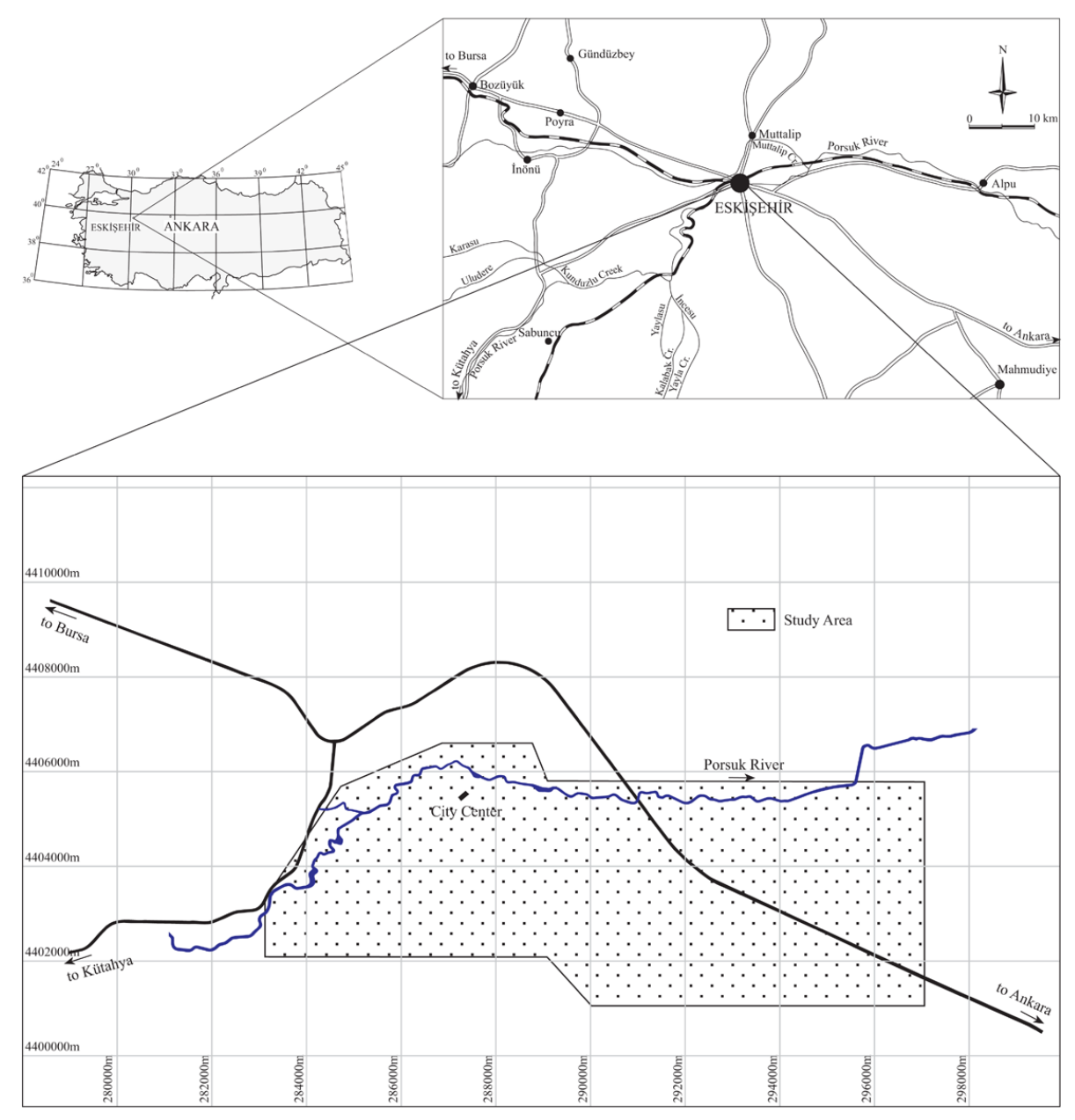

Fig. 1. Location map of the study area.

4.401.053-4.406.600N (UTM Zone 36, ED50) covers an area about $60 \mathrm{~km}^{2}$. The Porsuk River flows through the city from west to east and is the main stream in the region.

The area under investigation is surrounded by highlands in the South and the North; it presents a flat topography with very low angle slopes ranging between $0-10 \%$ in its northern and central parts. However, the southern slopes are between $10-40 \%$, indicating moderate slopes (Orhan, 2005). The elevation of the region varies between 790 and $1010 \mathrm{~m}$.

The geological formations are not complex in the province of Eskişehir. Metamorphic, volcanic and sedimentary rocks from the Triassic to Quaternary ages are the main geological units in the region. The generalized geological map of the city and its surroundings is shown in Fig. 2. The oldest units in the North of the study area are grouped into tectonic units consisting of Triassic-aged Eskiehir Metamorphics, Karkın Formation and ophiolitic rocks. A Lower Eocene-aged Mamuca Formation is overlying these units unconformably in the southern part. The Upper Miocene-aged Porsuk Formation overlies the Mamuca Formation with an angular disconformity. A Pliocene-aged Ilıca Formation overlies the older units conformably. The recent formations in the study area could be separated into two units: Pleistocene aged Akçay Formations and Quaternary Alluvium (Gözler et al., 1996).

In the study area the main drainage system is dominated by the Porsuk River. The Porsuk River comes from a southwest direction, flows through the city from west to east and flowing eastwards, to where it leaves the city border. Sarısu Creek flows in an east west direction through Kütahya and it joins the Porsuk River northwest of the city center. The Porsuk River is used for irrigation purposes in the Eskiehir Basin. Its average altitude in the study area is $790-800 \mathrm{~m}$ a.s.l. and from the river, water is conducted through canals to different regions in the city.

Quaternary Alluvium, which is formed by transported materials through the Porsuk River and Sarısu Creek, is the most important formation as an aquifer in the study area. The Alluvium is located in the Southeast of the study area at the junction of Porsuk River and Sarısu Creek and in the city center at places near the Porsuk River, its thickness reaches about 20 and $25 \mathrm{~m}$, respectively (DSI, 2001a, b). 


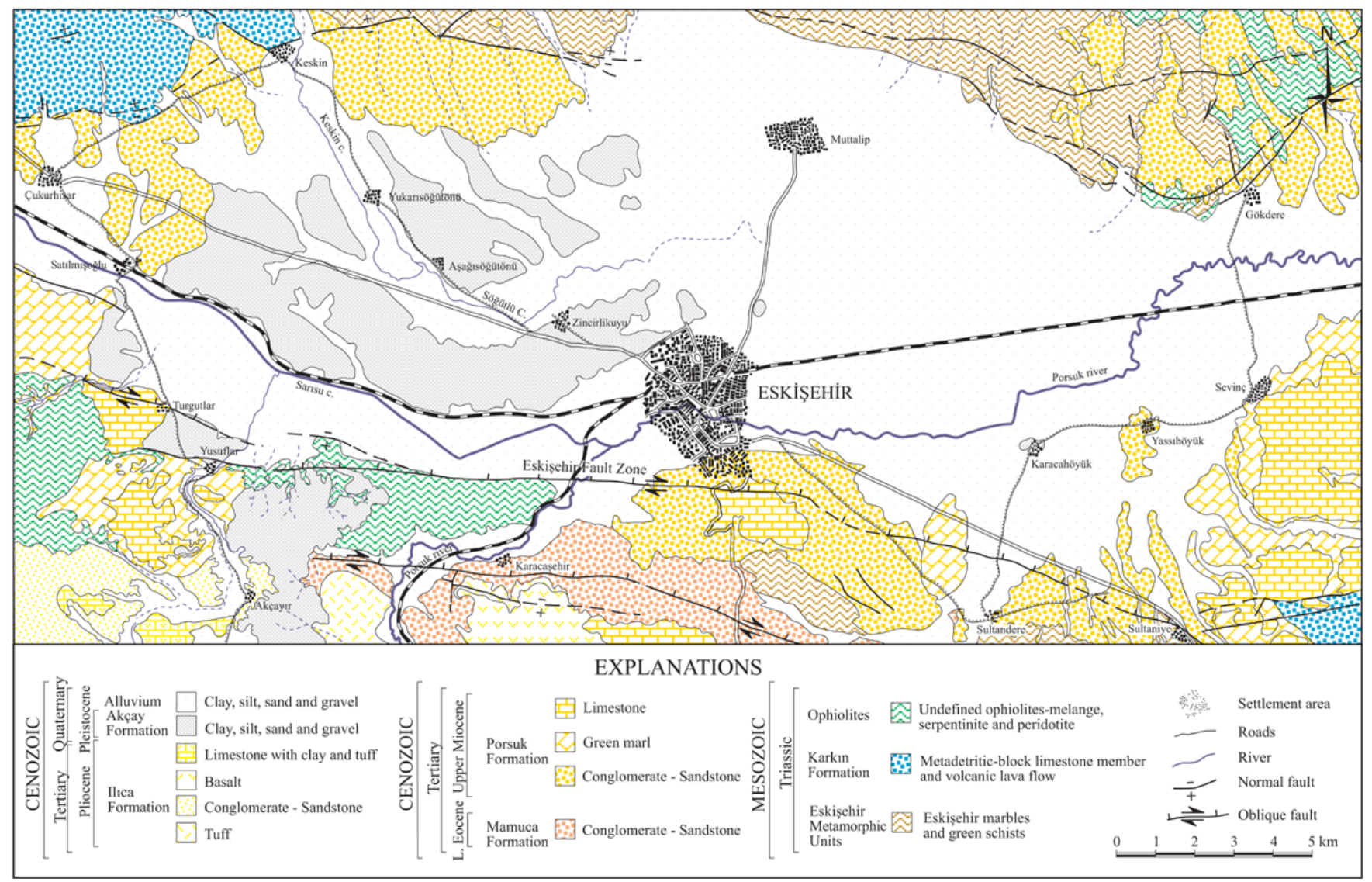

Fig. 2. Generalized geological map of Eskisehir and its vicinity (Orhan, 2005).

From the records of the boreholes, it is evident that the groundwater table is generally shallow. The groundwater level is closely associated with the amount of precipitation and may be quite high when monthly precipitation is high. In the highest precipitated season (i.e. April-May), the ground water level varies between $0.5-7.5 \mathrm{~m}$, even at some locations its depth varies between $20-30 \mathrm{~m}$. In the season with the lowest precipitation (i.e. July-August), the groundwater level changes between 2 and $13 \mathrm{~m}$. The Pleistocene aged Akçay Formation which lies in the northeastern part of the study area, has secondary importance as an aquifer and its groundwater level is deeper than that of the Quaternary Alluvium. The groundwater level variation in the basin is between 0.1 and $1.5 \mathrm{~m}$; especially in the city center the variation is even smaller and is between 0.1 and $0.5 \mathrm{~m}$. Figure 3 illustrates the static ground water table variation in the basin. As illustrated in Fig. 3, the ground water depth changes between 2 and $4 \mathrm{~m}$. In the rock units in the South of the study area, no groundwater is observed. The direction of the groundwater flow through the aquifer is mostly towards the north in Eskiehir city. High ground water levels and alluvial soils have a high potential risk for damage due to liquefaction, especially in seismically active settlement areas.

\section{Seismotectonics of the study area}

Eskişehir is situated within the second degree earthquake region on the seismic hazard zonation map of Turkey published by the Ministry of Reconstruction and Settlement (1996). The seismotectonics of the study area were reevaluated using earthquake records collected by the National Disaster Organization, and the map of active faults of Turkey constructed by Şaroğlu et al. (1992).

As a result of the detailed seismological survey, four seismic sources were delineated. These are the North Anatolian Fault Zone (NAFZ), the Eskişehir Fault Zone (EFZ), the Kütahya Fault Zone (KFZ) and the Simav Fault Zone (SFZ) (Fig. 4).

The well known NAFZ is a strike-slip fault with a total length of $1400 \mathrm{~km}$ and it is divided into two branches in the Marmara Sea Region; only the southern branch was taken into account for this study. Numerous large earthquakes have occurred, both in recent and historical time. For the study area, one of the most important earthquakes is the 1957 Abant earthquake that occurred on this segment with a magnitude of 7.1. Ambraseys (1988) reported that the above earthquake was associated with a faulting extending from northeast of Lake Abant to near the Dokurçun area. 


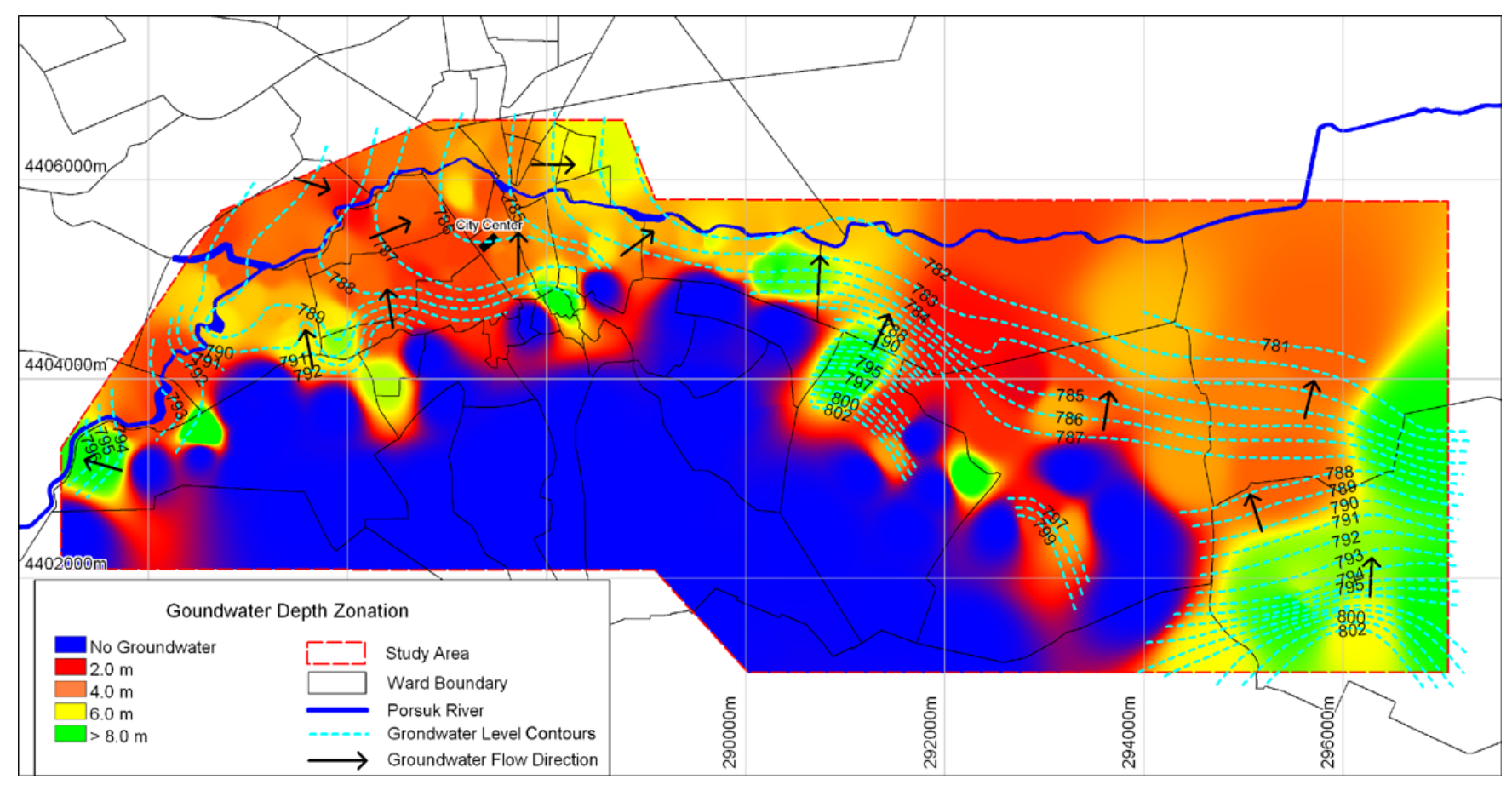

Fig. 3. Groundwater level contour and depth zonation map of the study area.

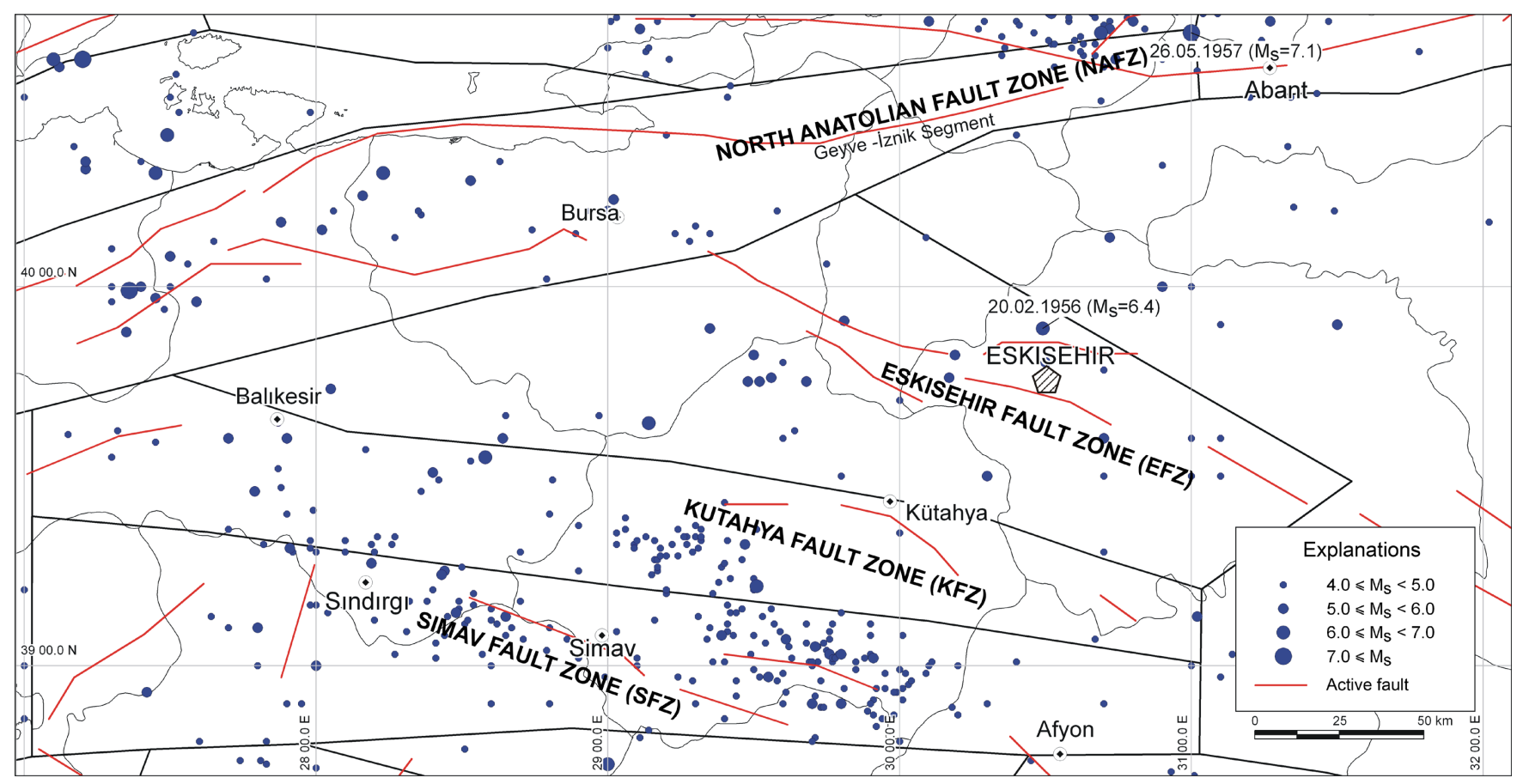

Fig. 4. Seismic sources and earthquakes that occurred during the last 100 years.

The WNW-ESE-orientated Eskişehir Fault Zone which separates the Aegean-western Anatolian block from the central Anatolian block is a right lateral strike-slip fault zone with a normal component. The fault zone is character- ized by fault segments which trend from E-W to NW-SE around Eskişehir. The largest earthquake that has occurred on Eskişehir fault zone is the February 1956 earthquake with a magnitude of $M_{\mathrm{s}}=6.4$. The fault plane solution of the 


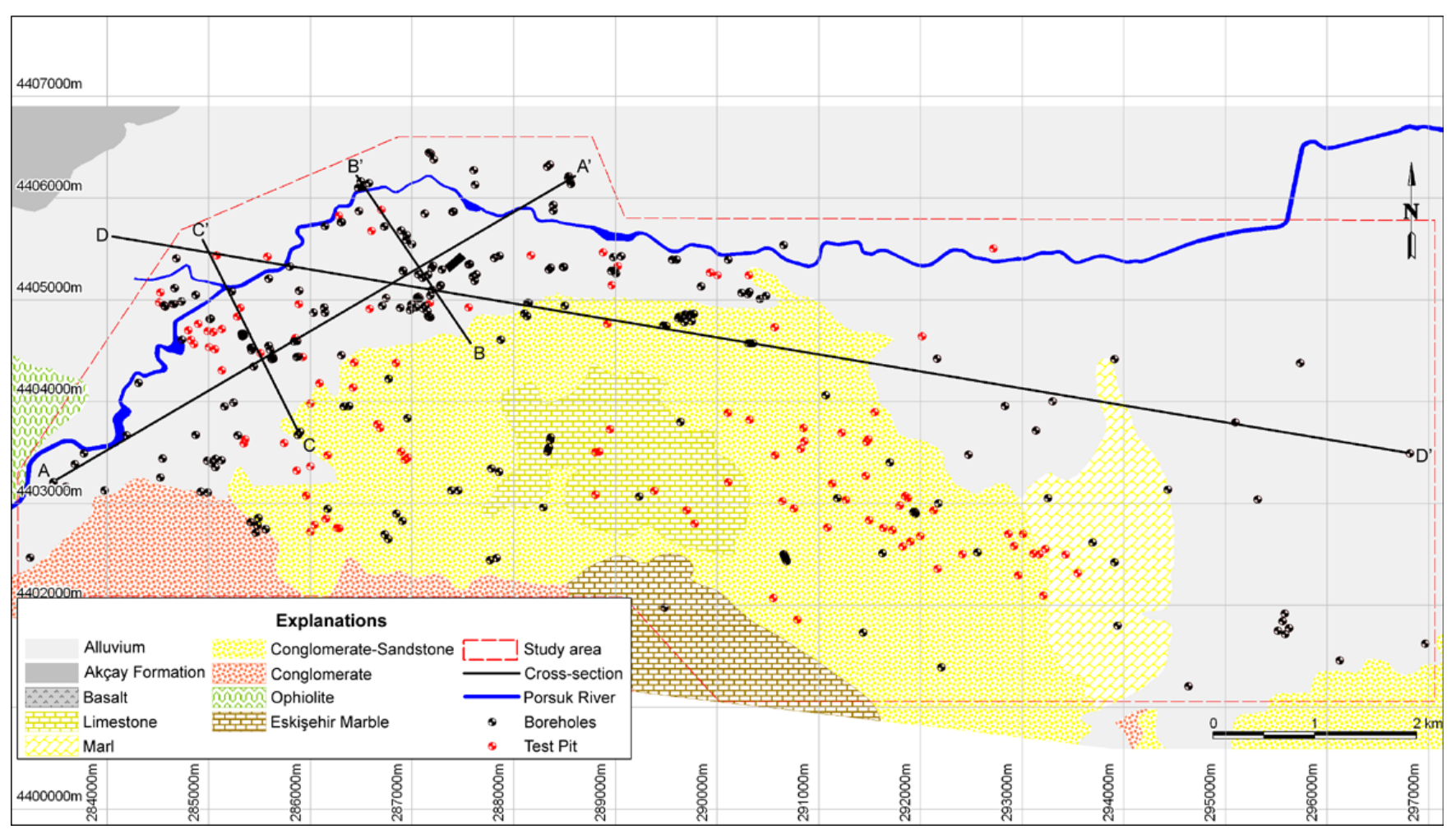

Fig. 5. A general overview of the field work.

1956 earthquake and field observations indicate that the EFZ is a trantensional fault zone and plays an important role in the development of Eskiehir and İnönü plains (Altunel and Barka, 1998).

The Kütahya Fault Zone is situated in the Southwest of Eskişehir. It is composed of three main segments. One of the most important earthquakes recorded around this fault was the 1970 Çavdarhisar earthquake with a magnitude of 5.9 and a focal depth of $18 \mathrm{~km}$ (Genç, 2004).

Simav is one of the graben systems of Western Anatolia, which is mainly controlled by the extensional neotectonic regime of the Aegean Region of Turkey. Simav fault trends nearly WNW-ESE for $100 \mathrm{~km}$, along the Simav River from Sindirgi at the West to Muratdagi at the East. The fault is not a single fracture; instead it consists of several step faults parallel to the main fracture (Oygür, 1997).

\section{Field investigations}

Geotechnical investigations on alluvium were performed in two stages: field and laboratory. In the field stage, 232 boreholes in different locations with a total length of $2509.2 \mathrm{~m}$ were drilled to obtain disturbed and undisturbed soil samples and determine the ground water level. The depths of the boreholes ranged between 4.5 and $22.0 \mathrm{~m}$. Most of the data is on average to a depth of $10 \mathrm{mb}$.g.l. Test pits at
106 different locations were also excavated to complement the geotechnical data obtained from the boreholes. The locations of the boreholes, test pits and cross-sections are illustrated in Fig. 5.

During the field investigations, 1328 SPT tests were performed according to ASTM D-1586 test specifications (American Society for Testing and Materials, 2000). SPT was performed at $1.5-\mathrm{m}$ intervals in the boreholes by using a donut-type hammer with the rope.

Throughout the study area, different soil types are observed. The lowest SPT blow counts are observed in regions close to the Porsuk River (Fig. 6). In some places at the top with a depth of $5.0 \mathrm{~m}$, the average value of SPT is 5 , even at some places the values fall below 5 . At lower levels, the SPT counts increase and the consistency of the soils at these depths can be defined as dense to very dense. In the study area in shallow depths and especially in the city center along the Porsuk River, low SPT blow counts are observed. Whereas at deeper levels, except in regions close to the Porsuk River, high SPT values are obtained. At depths between 5.0 and $5.5 \mathrm{~m}$, dense sand and sandy gravel are distinguished and therefore, the SPT blow counts are increased. At deeper levels the SPT blow counts are observed as 40-50. As a result, the SPT indicates the presence of some layers prone to liquefaction in regions especially close to the Porsuk River. 

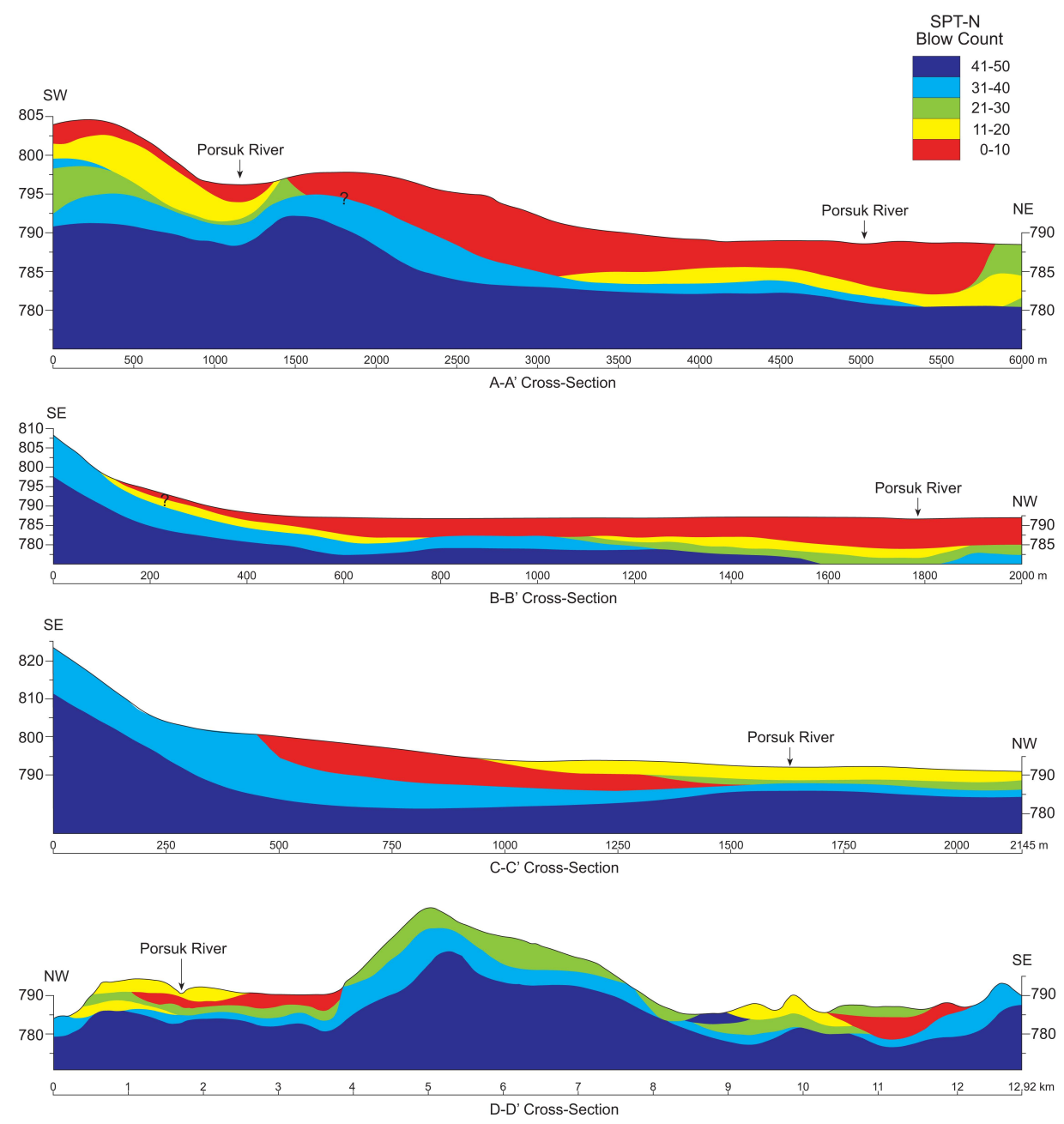

Fig. 6. Distribution of SPT-N blow counts for different cross-sections.

\section{Laboratory investigations}

Following the field investigation, laboratory testing was performed to determine Atterberg limits and physical properties of disturbed and undisturbed soil samples. The major part of the study area consists of alluvium with fine grained soils in the upper levels and coarse grained soils in the lower levels. Figure 7 shows the grain-size distribution curves in connection to the upper and lower bound curves for liquefaction susceptibility by Iwasaki (1986). In this figure, the upper and lower bounds of the grain size distribution curves are used for efficient presentation. As seen in this figure, it is clear those soils are prone to liquefaction. The grain size distribution analyses shows that all samples are composed, on average, of $4.1 \%$ gravel, $30.9 \%$ sand and $65.0 \%$ fines (silt-clay). The statistical evaluation of the coarse and fine grained soils is given in Table 1.

The fine grained soils in the study are composed, on average, of $1.5 \%$ gravel, $26.7 \%$ sand and $71.8 \%$ fines (silt-clay). The Atterberg limits of these samples in the study area are quite variable. The liquid limit values vary between 30.0 and
$92.0 \%$ and the average is $54.9 \%$. The plasticity index of the same samples also varies in a wide range (3-53), whereas the average value is obtained as $26.2 \%$. The fine grained soils in the northern and northeastern part of the study area are especially in low plastic character, their sand content is high. According to the Unified Soil Classification System (USCS), these soils can be classified as sandy-clayey silt and low plastic clay-silt (CL-ML). The fine grained soils in the southern and southwestern parts are high plasticity soils and can be classified as high plastic clay-silt (CH-MH).

Coarse grained soils consist of sand and gravel and build the bottom layer of alluvium. These dense soils are classified as silty sand, poor and well graded soils (SM-GM, SP-GP, and SW-GW) and they are composed, on average, of $15.9 \%$ gravel, $50.2 \%$ sand and $33.9 \%$ fines (silt-clay). The consistency limits of the samples vary also in a wide range. The liquid limit values vary between $27.0-93.0 \%$ and the average is $46.8 \%$. The plasticity index of the same samples also varies in a wide range (3-45), whereas the average value is obtained as $19.3 \%$. 
Table 1. Statistical summary of the geotechnical properties of the soil samples.

\begin{tabular}{|c|c|c|c|c|c|c|}
\hline & \multirow{2}{*}{$\begin{array}{l}\text { Soil properties } \\
\text { Soil properties }\end{array}$} & \multirow{2}{*}{$\begin{array}{l}\text { Sample } \\
\text { number }\end{array}$} & \multicolumn{4}{|c|}{ Value } \\
\hline & & & Minimum & Maximum & Average & Standard deviation \\
\hline \multirow{9}{*}{ 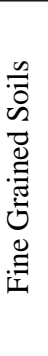 } & Grain size distribution & & & & & \\
\hline & $<0.075 \mathrm{~mm}(\%)$ & 390 & 50.0 & 98.0 & 71.8 & 9.0 \\
\hline & $<4.75 \mathrm{~mm}(\%)$ & 390 & 78.0 & 100.0 & 98.5 & 3.3 \\
\hline & Atterberg limits & & & & & \\
\hline & Liquid limit (\%) & 386 & 30.0 & 92.0 & 54.9 & 12.2 \\
\hline & Plastic limit (\%) & 385 & 18.0 & 51.0 & 28.7 & 4.6 \\
\hline & Plasticity index (\%) & 385 & 3.0 & 53.0 & 26.2 & 10.3 \\
\hline & Water content $(\%)$ & 388 & 4.8 & 53.3 & 31.9 & 9.7 \\
\hline & Natural density $\left(\mathrm{Mg} \mathrm{m}^{-3}\right)$ & 304 & 1.49 & 2.20 & 1.81 & 0.11 \\
\hline \multirow{9}{*}{ 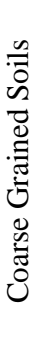 } & Grain size distribution & & & & & \\
\hline & $<0.075 \mathrm{~mm}(\%)$ & 85 & 6.0 & 49.0 & 33.9 & 11.7 \\
\hline & $<4.75 \mathrm{~mm}(\%)$ & 85 & 35.0 & 100.0 & 84.1 & 16.1 \\
\hline & Atterberg limits & & & & & \\
\hline & Liquid limit (\%) & 67 & 27.0 & 93.0 & 46.8 & 15.6 \\
\hline & Plastic limit (\%) & 66 & 19.0 & 58.0 & 27.7 & 6.8 \\
\hline & Plasticity index (\%) & 66 & 3.0 & 45.0 & 19.3 & 11.8 \\
\hline & Water content $(\%)$ & 75 & 3.1 & 48.8 & 23.0 & 10.7 \\
\hline & Natural density $\left(\mathrm{Mg} \mathrm{m}^{-3}\right)$ & 35 & 1.68 & 2.10 & 1.90 & 0.11 \\
\hline
\end{tabular}

\section{Determination of seismic hazard parameters}

An important step in liquefaction potential assessment is the quantitative estimation of the level of ground shaking that is likely to be experienced in the area under investigation, i.e. the site-specific seismic hazard analysis (Beroya and Aydin, 2008). Deterministic Seismic Hazard Analysis (DSHA) and Probabilistic Seismic Hazard Analysis (PSHA) are widely used for describing earthquake ground motions in geotechnical engineering.

The data on historical and instrumentally recorded earthquakes for Turkey and its surrounding vicinity, collected from the Earthquake Research Center (ERD) of the General Directorate of Disaster Affairs of Turkey, are considered as a basis of seismic hazard calculations. Earthquakes of magnitudes greater than 4.0 are included in the analyses reported herein. Four seismic sources have been selected to assess the seismic hazard of Eskiehir. These are NAFZ, EFZ, KFZ, SFZ as illustrated in Fig. 4.

In this study, PSHA methodology based on Cornell (1968) has been applied to Eskişehir city. For each source, the maximum earthquake magnitude was determined using the empirical relationships proposed by Wells and Coppersmith (1994). Once the maximum earthquake magnitude was determined, a linear regression was performed to estimate the coefficients of the Gutenberg-Richter (1944) relationship, using the computer program DAMHA which was developed at the Earthquake Research Center, Eskişehir Osmangazi University as given in Table 2 .
Peak ground accelerations (PGA) at rock sites were determined using the attenuation relationships proposed by Campbell (1981), Boore et al. (1993, 1997), Campbell and Bozorgnia (1994), Gülkan and Kalkan (2002). Linear-areal seismic source models are used for seismic hazard calculations. As a result of analyses, mean PGA value for the city center of Eskişehir is about $0.19,0.30$ and $0.47 \mathrm{~g}$ for 144,475 and 2475 years return period, respectively (Fig. 8). For liquefaction potential assessment, however, the specific magnitude of the design ground motion is required. As seen in Fig. 6, the hazard is mainly dominated by Eskişehir fault zone for the province of Eskişehir. Therefore, the scenario earthquake of $M=6.4$ was chosen for liquefaction analyses.

\section{Assessment of liquefaction potential}

Prediction of liquefaction potential of soil is based on cyclic laboratory testing on soil samples and the use of in-situ test and empirical methods. However, the use of laboratory testing is complicated due to difficulties associated with sample disturbance during both sampling and reconsolidation. Thus, empirical approaches based on the in-situ penetration test results have gained popularity in engineering practice as well as in engineering codes (Ansal and Tönük, 2007).

In this study, the simplified SPT-based method suggested by Youd et al. (2001) has been performed. Seed and Idriss (1971) proposed a simplified procedure termed as cyclic stress method. In this method, earthquake-induced loading characterized in terms of the cyclic stress ratio (CSR) 
Table 2. Seismic hazard parameters used in this study.

\begin{tabular}{lcccccc}
\hline Source zone & Fault type* & $\begin{array}{c}\text { Largest observed } \\
\text { earthquake magnitude } \\
\text { (from 1907 to present) }\end{array}$ & $a$ & $b$ & $M_{\min }$ & $M_{\max }{ }^{* *}$ \\
\hline North Anatolia Fault Zone (NAFZ) & $\mathrm{SS}$ & 7.1 & 4.28 & 0.63 & 4.0 & 7.6 \\
Eskişehir Fault Zone (EFZ) & RLSS + N & 6.4 & 4.22 & 0.63 & 4.0 & 6.4 \\
Simav Fault Zone (SFZ) & $\mathrm{N}$ & 5.9 & 6.82 & 1.00 & 4.0 & 6.5 \\
Kütahya Fault Zone (KFZ) & $\mathrm{N}$ & 6.1 & 4.57 & 0.76 & 4.0 & 6.3 \\
\hline
\end{tabular}

* SS: Strike Slip fault, RLSS: Right Lateral Strike Slip fault, N: Normal fault, ** from Wells and Coppersmith (1994).

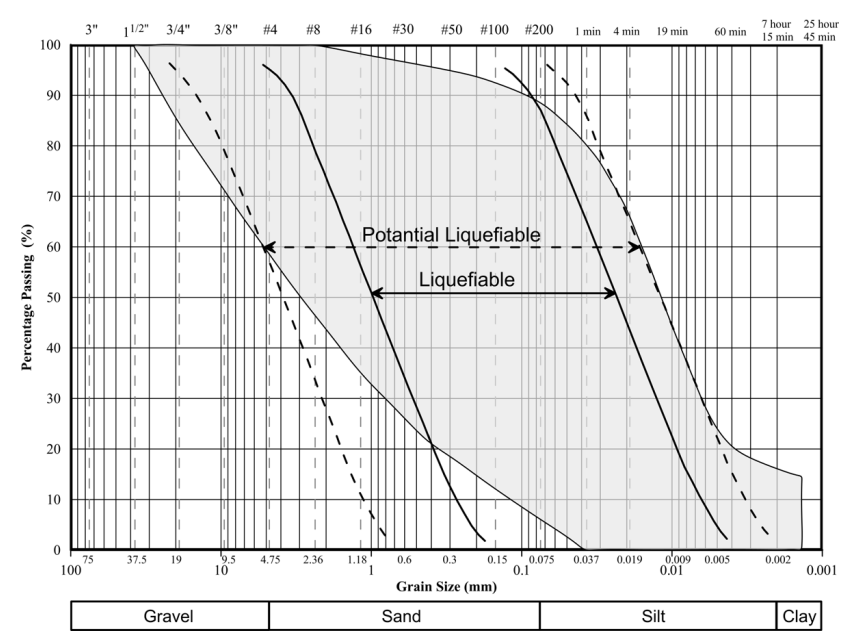

Fig. 7. Grain size distribution range of the soil samples.

is compared to the liquefaction resistance represented in terms of the cyclic resistance ratio (CRR). The CSR is calculated by the Eq. (1) as follows:

$\mathrm{CSR}=\frac{\tau_{\mathrm{av}}}{\sigma_{\mathrm{vo}}^{\prime}}=0.65\left(a_{\max } / g\right)\left(\sigma_{\mathrm{vo}} / \sigma_{\mathrm{vo}}^{\prime}\right) r_{\mathrm{d}}$

where $a_{\mathrm{max}}$ is maximum ground surface acceleration in $\mathrm{g}, g$ is acceleration of gravity $\left(9.81 \mathrm{~m} \mathrm{~s}^{-2}\right), \sigma_{\mathrm{vo}}$ and $\sigma_{\mathrm{vo}}^{\prime}$ are total and effective vertical stress, $r_{\mathrm{d}}$ is a stress reduction factor. This factor is calculated from Eqs. (2) and (3). Liao and Whitman (1986) proposed these equations for $z \leq 9.15 \mathrm{~m}$ and $9.15 \mathrm{~m}<z \leq 23 \mathrm{~m}$, respectively.

$r_{\mathrm{d}}=1-0.00765 z$

$r_{\mathrm{d}}=1.174-0.0267 z$

The more comprehensive alternative is to calculate the average shear stress with depth using site response analyses depending on the soil stratification and stiffness of the soil layers (Ansal and Tönük, 2007).

CRR expresses the capacity of the soil to resist liquefaction. This term is determined from the curves which show the correlation between corrected SPT blow-count $N_{1(60)}$ and the

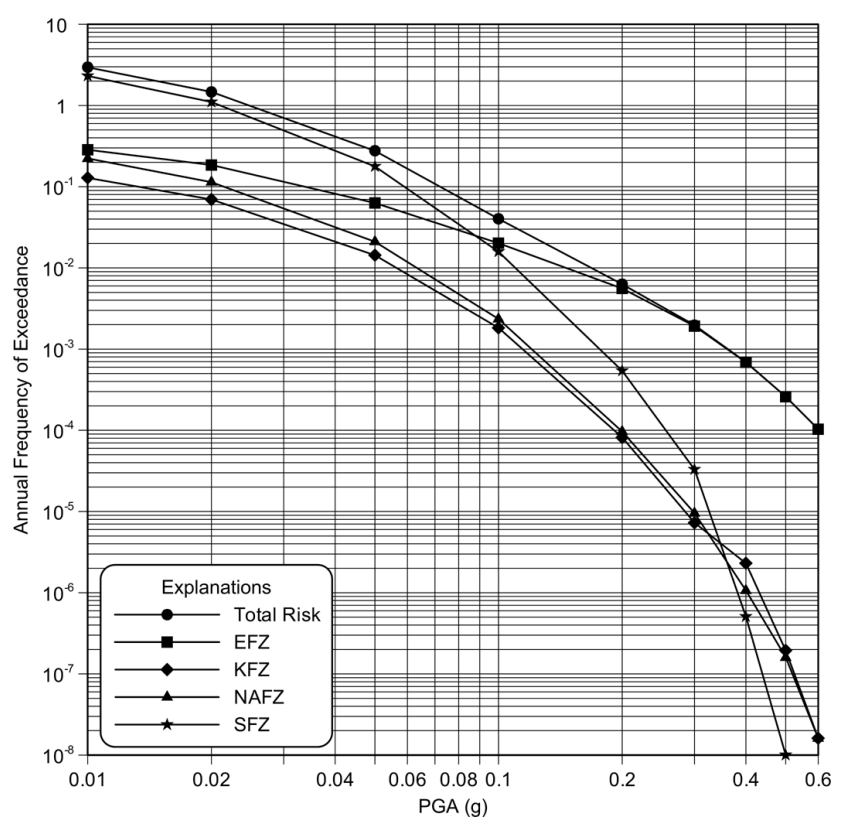

Fig. 8. Mean seismic hazard curves for the study area.

Cyclic Stress Ratio. These curves are developed for granular soils with the fines contents of $5 \%$ or less, $15 \%$ and $35 \%$ (Youd et al., 2001).

The corrected blow count $N_{1(60)}$ is determined as follows:

$N_{1(60)}=N_{\mathrm{m}} C_{\mathrm{N}} C_{\mathrm{E}} C_{\mathrm{B}} C_{\mathrm{R}} C_{\mathrm{S}}$

In Eq. (7), $N_{\mathrm{m}}$ is a uncorrected SPT blow-count; $C_{\mathrm{N}}, C_{\mathrm{E}}, C_{\mathrm{B}}$, $C_{\mathrm{R}}$ and $C_{\mathrm{S}}$ are correction factors for effective overburden stress, hammer energy ratio, borehole diameter, rod length and samplers with or without liners, respectively. In this study, SPT is performed by using a donut-type hammer with the rope. For this equipment, rod-energy ratio of $45 \%$ is accepted (Seed and De Alba, 1986). $C_{\mathrm{N}}$ is calculated from the Eq. (5) developed by Liao and Whitman (1986).

$C_{\mathrm{N}}=\sqrt{\frac{P_{\mathrm{a}}}{\sigma_{\mathrm{vo}}^{\prime}}}$ 
where $\sigma_{\mathrm{vo}}^{\prime}$ is effective overburden stress, $P_{\mathrm{a}}$ is atmospheric pressure $(100 \mathrm{kPa})$. The remaining corrections are taken into account as given in Youd et al. (2001).

The results of the liquefaction assessment are presented with a factor of safety (FS) against liquefaction (Eq. 6).

$\mathrm{FS}=\frac{\mathrm{CRR}_{7.5}}{\mathrm{CSR}} \mathrm{MSF}$

CRR curves represent the liquefaction susceptibility for a magnitude of 7.5. Therefore, the factor of safety is multiplied with a magnitude scaling factor (MSF). Various values of MSF have been proposed based on empirical data (Youd et al., 2001). For this study, the MSF suggested by Seed and Idriss (1982) is used for analyses.

It should be noted that liquefaction analyses are performed for three different peak ground acceleration levels as 0.19 , 0.30 and $0.47 \mathrm{~g}$ with a scenario earthquake of $M=6.4$. The liquefaction assessments are carried out with 402 SPT blow counts in the investigation area. the liquefaction potential of the silty and clayey soils was studied according to the procedure of Seed et al. (2003). It should be noted that the layers with $N_{1(60)}$ values greater than 30 or above ground water level have been classified as non-liquefiable.

In this study, three definitions of the factor of safety for liquefaction potential are proposed: liquefiable $(\mathrm{FS} \leq 1.0)$, marginally liquefiable $(1<\mathrm{FS} \leq 1.2)$ and non-liquefiable (FS > 1.2).

The results of the analyses are presented with a two different point of view (Figs. 9 and 10).

In Fig. 9, data marked as liquefiable are composed of silt with low plasticity, silty sand and mixture of gravel and sand. It should be noted that samples falling to the left of the curve $(\mathrm{FC}=35 \%)$ and classified as non-liquefiable soils are above the ground water level. $90.5 \%$ of the samples are nonliquefiable, $6.9 \%$ of the samples are liquefiable and $2.6 \%$ is marginally liquefiable (for $0.19 \mathrm{~g}$ ). When peak ground acceleration is equal to $0.30 \mathrm{~g}, 28.4 \%$ of the samples are liquefiable and $6.7 \%$ of the samples are marginally liquefiable. Obviously stronger liquefaction effects $(40 \%)$ are observed under an acceleration of $0.47 \mathrm{~g}$.

The variation of the factor of safety with depth against liquefaction is given in Fig. 10. It is expressed in the previous sections that the major part of the study area consists of alluvium with fine grained soils in the upper level (1-4 m) and coarse grained soils below this level. It is clear that most of the liquefiable and marginally liquefiable samples are in the range of 4-10 $\mathrm{m}$ depth below the ground surface. All the liquefiable zones correspond to layers of silt, silty sand and a mixture of gravel and sand. However, liquefaction is not expected in sandy layers and layers of sand-gravel mixtures at a greater depths $(>10.0 \mathrm{~m})$ due to their higher relative densities. According to this figure, the liquefaction potential is very low for depths less than $4.0 \mathrm{~m}$. This situation can be explained by the ground water level position. As illustrated in Fig. 3, the ground water depth changes between 2 and $4 \mathrm{~m}$.

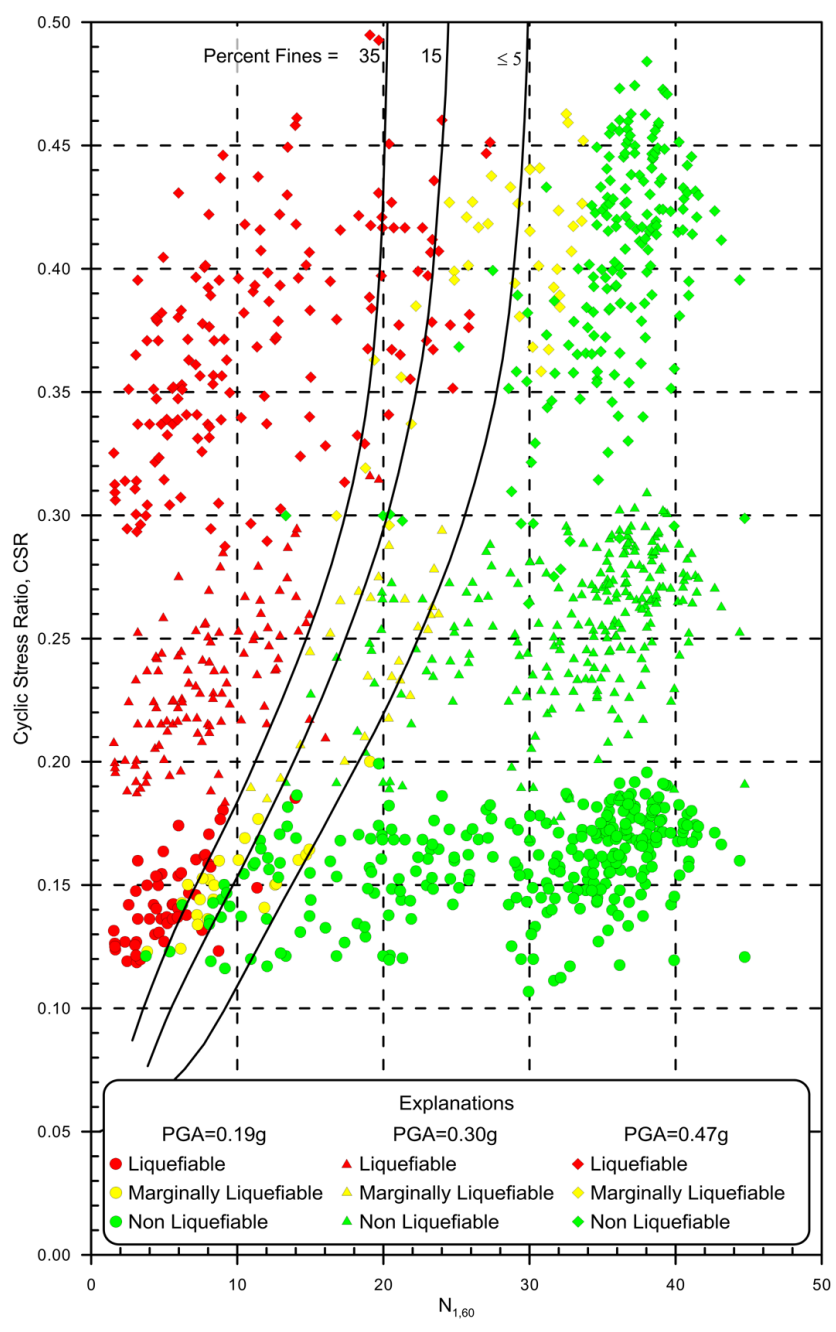

Fig. 9. Cyclic stress ratio and SPT $N_{1,60}$ plot based on Youd et al. (2001).

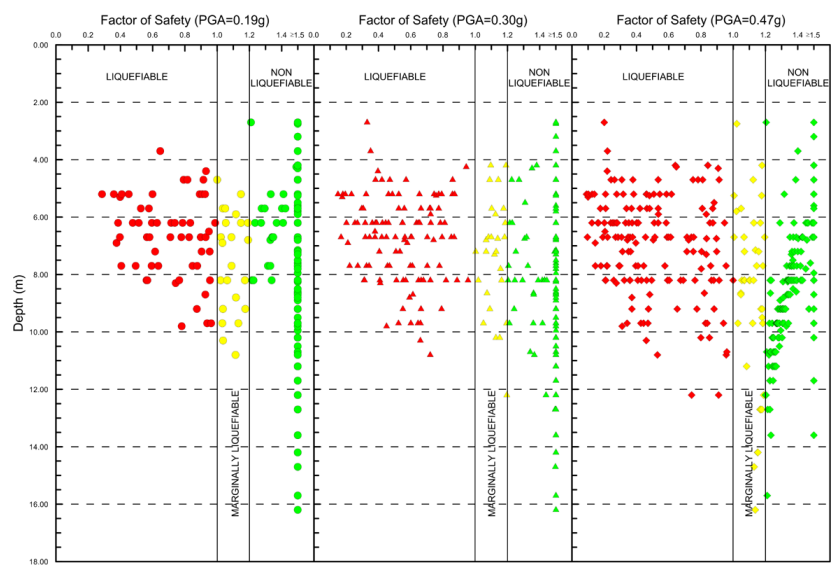

Fig. 10. Variation of safety factor versus liquefaction depth (a) $\mathrm{PGA}=0.19 \mathrm{~g}$, (b) $\mathrm{PGA}=0.30 \mathrm{~g}$ and $(\mathbf{c}) \mathrm{PGA}=0.47 \mathrm{~g}$. 

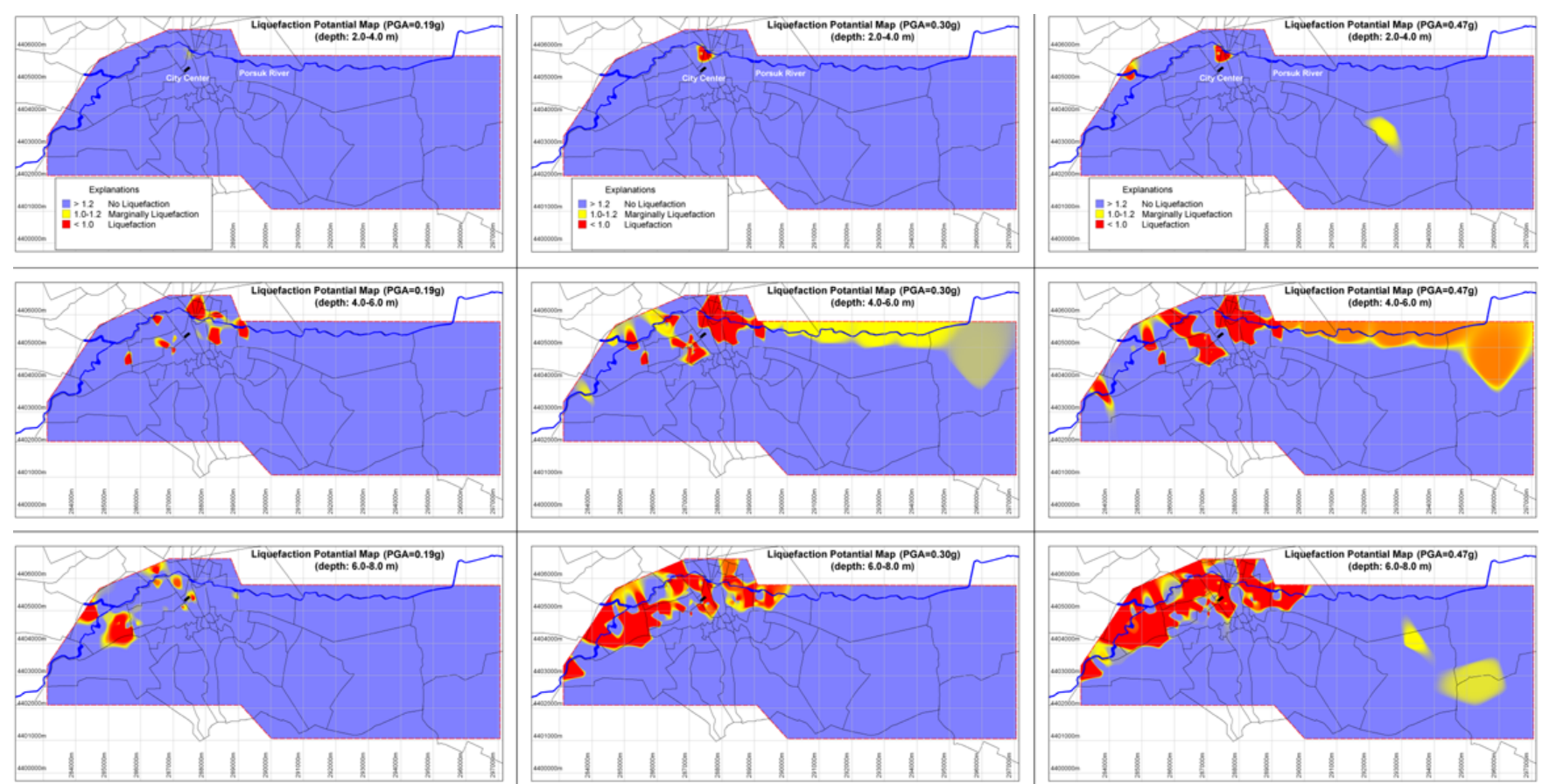

Fig. 11. Liquefaction potential map of the study area.

\subsection{Liquefaction potential mapping}

Liquefaction hazard maps are useful tools for identifying areas with a high likelihood of liquefaction-induced ground deformation. Information about areas with a high likelihood of ground deformation can be used for effective regional earthquake hazard planning and mitigation (Heidari and Andrus, 2010).

In the last decade, with the advances in computer technologies, geographic information systems (GIS) are frequently used to produce hazard maps. For the study area, liquefaction potential maps are created by means of GIS software. For this purpose, factors of safety calculated at different depth intervals (i.e. 2-4, 4-6 and 6-8 $\mathrm{m}$ below the surface) are spatially evaluated. For this process, it should be noted that the geological setting and ground water level are also considered. Different liquefaction potential maps are established by repeating the same procedure for each acceleration level (i.e. 0.19, 0.30 and $0.47 \mathrm{~g}$ ). These maps are illustrated in Fig. 11. Three factors of safety definitions, described in previous section, are used in the stage of the creation of liquefaction potential maps.

\section{Discussion and results}

As seen in Fig. 11, when peak ground acceleration is equal to $0.19 \mathrm{~g}$, high liquefaction potentially areas are not observed in 2-4-m depth interval. However, in the city center, two different restricted areas have a high liquefaction potential at a high acceleration level. The main reason for the low liquefaction potential for this level is that these soil deposits mainly consist of fine grained soils.

The liquefaction potential maps created for the second level (i.e. 4-6-m interval below the surface) differ from the previously created one. On the map prepared for a condition in which peak ground acceleration is $0.30 \mathrm{~g}$, the liquefiable regions spread and they cover a significant part of the city center. For an acceleration of $0.47 \mathrm{~g}$, a higher liquefaction potential is observed in an extended region. Besides, at the eastern part of the liquefiable region, probable liquefiable regions have appeared. The soil deposits in this level are mainly composed of loose sand-silt material; therefore they increase the liquefaction possibility.

The liquefaction potential map prepared for the 6-8-m interval shows similarity with the previously developed one. A relatively small area is illustrated as liquefiable soil for $0.19 \mathrm{~g}$, while a larger area is liquefiable for $0.30 \mathrm{~g}$. Much larger areas are illustrated as liquefiable for $0.47 \mathrm{~g}$. It is clear that potential liquefiable regions are transformed into liquefiable ones. Potential liquefiable regions also appear in some regions outside the city center for this hazard level. In a region at the northeastern part of the study area at high acceleration level, liquefiable and potential liquefiable regions appear.

The authors of this work believe that liquefaction potential maps can be used effectively for development plans and risk management practices in Eskişehir. Results of the analyses 
indicate that the presence of high ground water level and alluvial soil increase the liquefaction potential with the seismic features of the region.

It is obvious that a further study to determine in-situ cyclic stress ratio by means of site-specific ground response analyses might result in more comprehensive estimates to be used for liquefaction assessments, especially when combined with cyclic triaxial test results.

Acknowledgements. This study was supported by ESOGU Research Foundation Grant No: 200315048.

Edited by: M. E. Contadakis

Reviewed by: two anonymous referees

\section{References}

Altunel, E. and Barka, A.: Neotectonic activity of Eskişehir Fault Zone between Inönü and Sultandere, Geological Bulletin of Turkey, 41(2), 41-52, 1998 (in Turkish).

Ambraseys, N. N.: Engineering seismology, Earthq. Eng. Struct. D., 17, 1-105, 1988.

American Society for Testing and Materials: Standard Method for Penetration test and split barrel sampling of soils, Annual Book of ASTM Standards, Soil and Rock (1), Standard No. D 158699, 04.08, West Conshohocken, PA, 139-143, 2000.

Ansal, A. and Tönük, G.: Source and site effects for microzonation, Earthquake Geotechnical Engineering, 4th International Conference on Earthquake Geotechnical Engineering-Invited Lectures, Book Series Title: Geotechnical Geological and Earthquake Engineering, edited bY: Pitilakis, K., Geotechnical Geological and Earthquake Engineering, Chapter 4, 73-92, 2007.

Ansal, J., Bardet, P., Bray, J., Cetin, K. O., Durgunoglu, T., Erdik, M., Kaya, A., Ural, D., Yilmaz, T., and Youd, T. L.: Initial Geotechnical Observations of the August 17, 1999 Izmit Earthquake, Earthquake Engineering Research Center, September 1999.

Bardet, J. P., Oka, F., Sugito, M., and Yashima, A.: The Great Hanshin Earthquake disaster. Preliminary Investigation Rep., Dept. of Civil Engineering, Univ. of Southern California, Los Angeles, USA, 1995.

Beroya, M. A. A. and Aydin, A.: Seismic hazard analysis of Laoag City, Northern Philippines for liquefaction potential assessment, Eng. Geol., 96, 28-42, doi:10.1016/j.enggeo.2007.08.007, 2008.

Boore, D. M., Joyner, W. B., and Fumal, T. E.: Estimation of response spectra and peak accelerations from western North American earthquakes: An interim report, US Geol. Surv. Open-File Rep. 93-509, 72 pp., 1993.

Boore, D. M., Joyner, W. B., and Fumal, T. E.: Equations for estimating horizontal response spectra and peak acceleration from Western North American earthquakes: A summary of recent work, Seismol. Res. Lett., 68, 128-153, 1997.

Campbell, K. W.: Near-source attenuation of peak horizontal acceleration, B. Seismol. Soc. Am., 71(6), 2039-2070, 1981.

Campbell, K. W. and Bozorgnia, Y.: Near-source attenuation of peak horizontal acceleration from worldwide accelerograms recorded from 1957 to 1993, Proc. Fifth U.S. National Conference on Earthquake Engineering 3, Chicago, Illinois, July 10-14, 1994, 283-292, 1994.
Cetin, K. O., Seed, R. B., Der Kiureghian, A., Tokimatsu, K., Harder, L. F., Kayen, R. E., and Moss, R. E. S.: SPT-Based probabilistic and deterministic assessment of seismic soil liquefaction potential, J. Geotech. Geoenviron. Eng.-ASCE, 130(12), 13141340, 2004.

Chu, B., Hsu, S., and Chang, Y.: Ground behavior and liquefaction analyses in central Taiwan-Wufeng, Eng. Geol., 71(1-2), 119139, doi:10.1016/S0013-7952(03)00129-7, 2004.

Cornell, C. A.: Engineering seismic risk analysis, B. Seismol. Soc. Am., 58, 1583-1606, 1968.

DSİ (General Directorate of State Hydraulic Works): Eskişehir OdunpazarıMunicipality Geophysical Resistivity Report, General Directorate of State Hydraulic Works, 3rd District, Eskişehir, unpublished, 6 pp., 2001a (in Turkish).

DSİ (General Directorate of State Hydraulic Works): Eskişehir Tepeba1Municipality Geophysical Resistivity Report, General Directorate of State Hydraulic Works, 3rd District, Eskişehir, unpublished, 6 pp., $2001 \mathrm{~b}$ (in Turkish).

Genç, G.: Probabilistic seismic hazard assessment for Eskişehir, METU, Graduate School of Natural and Applied Sciences, Master thesis, 154 pp., 2004.

Gözler, Z., Cevher, F., Ergul, E., and Asutay, H. J.: The geology of middle Sakarya and its south, General Directorate of Mineral Research and Exploration Rep: 9973, 87 pp., 1996 (in Turkish).

Gutenberg, B. and Richter, C. F.: Frequency of earhquakes in California, B. Seismol. Soc. Am., 34, 185-188, 1944.

Gulkan, P. and Kalkan, E.: Attenuation modeling of recent earthquakes in Turkey, J. Seismol., 6(3), 397-409, doi:10.1023/A:1020087426440, 2002.

Heidari, T. and Andrus, R. D.: Mapping liquefaction potential of aged soil deposits in Mount Pleasant, South Carolina, Eng. Geol., 112, 1-12, doi:10.1016/j.enggeo.2010.02.001, 2010.

Holzer, T. L. (Ed.): The Loma Prieta, California, Earthquake of October 17, 1989 - Liquefaction, USGS Professional Paper 1551-B, 314 pp., 1998

Idriss, I. M. and Boulanger, R. W.: Semi-empirical procedures for evaluating liquefaction potential during earthquakes, Soil Dyn. Earthq. Eng., 26(2-4), 115-130, doi:10.1016/j.soildyn.2004.11.023, 2006.

Iwasaki, T.: Soil liquefaction studies in Japan, State-ofArt, Soil Dyn. Earthq. Eng., 5(1), 2-68, doi:10.1016/02677261(86)90024-2, 1986.

Liao, S. and Whitman, R. V.: Overburden correction factors for SPT in sand, J. Geotech. Eng.-ASCE, 112(3), 373-377, doi:10.1061/(ASCE)0733-9410(1986)112:3(373), 1986.

Mhaske, S. Y. and Choudhury, D.: GIS-based soil liquefaction susceptibility map of Mumbai city for earthquake events, J. Appl. Geophys., 70(3), 216-225, doi:10.1016/j.jappgeo.2010.01.001, 2010.

Ministry of Reconstruction and Settlement: Seismic Hazard Map of Turkey, 1996.

NCEER (National Center for Earthquake Engineering Research): Proceedings of the NCEER workshop on evaluation of liquefaction resistance of soils, Technical Rep. No. NCEER-97-0022, edited by: Youd, T. L. and Idriss, I. M., SUNY, Buffalo, NY, USA, 1997.

Novikova, T., Papadopoulos, G. A., and Karastathis, V.: Evaluation of ground motion characteristics, effects of local geology and liquefaction susceptibility: the case of Itea, Corinth Gulf 
(Greece), Nat. Hazards, 40(3), 537-552, doi:10.1007/s11069006-9018-9, 2007.

Orhan, A.: The geo-engineering properties of foundation soils in southern part of Eskişehir city center and applying of geographic information system, Eskişehir Osmangazi Univertsity, Graduate School of Natural and Applied Sciences, Ph.D. thesis, 125 pp., 2005 (in Turkish).

Oygür, V.: Metallogeny of the Simav Graben (Inner-Western Anatolia, Turkey), METU, Graduate School of Natural and Applied Sciences, Ph.D. thesis, 144 pp., 1997.

Şaroğlu, F., Emre, O., and Kuşcu, İ.: Active Fault Map of Turkey, General Directorate of Mineral Research and Exploration, Ankara, 1992.

Seed, H. B.: Soil liquefaction and cyclic mobility evaluation for level ground during earthquakes, J. Geotech. Eng.-ASCE, 105(2), 201-255, 1979.

Seed, H. B. and De Alba, P.: Use of SPT and CPT Tests for Evaluating the Liquefaction Resistance of Sands, Use of In-situ tests in Geotechnical Engineering, ASCE-Geotech. Spec. Publ., 6, 281302, 1986.

Seed, H. B. and Idriss, I. M.: Analysis of soil liquefaction: Niigata earthquake, J. Soil Mech. and Foundation Div., Proc. ASCE, SM3, 83-108, 1967.

Seed, H. B. and Idriss, I. M.: Simplified procedure for evaluating soil liquefaction potential, J. Geotech. Eng.-ASCE, 97(9), 12491273, 1971.

Seed, H. B. and Idriss, I. M.: Ground motion and soil liquefaction during earthquakes, Earthquake Engineering Research Institute Monograph Series, Oakland, CA, USA, 134 pp., 1982.

Seed, H. B., Tokimatsu, K., Harder, L. F., and Chung, R. M.: The influence of SPT procedures in soil liquefaction resistance evaluations, J. Geotech. Eng.-ASCE, 111(12), 1425-1445, doi:10.1061/(ASCE)0733-9410(1985)111:12(1425), 1985.
Seed, R. B., Cetin, K. O., Moss, R. E. S., Kammerer, A., Wu, J., Pestana, J. M., Riemer, M. F., Sancio, R. B., Bray, J. D., Kayen, R. E., and Faris, A.: Recent advances in soil liquefaction engineering: a unified and consistent framework, Keyynote Address, 26th Annual ASCE Los Angeles Geotechnical Spring Seminar, Keynote Presentation, H.M.S. Queen Mary, Long Beach, California, 30 April 2003.

Seyrek, E.: Liquefaction problem in foundation soil of earthfill dam and a case study, Msc thesis, Graduate School of Natural and Applied Sciences, Eskisehir Osmangazi University, Eskisehir, 2003.

Wells, D. L. and Coppersmith, K. J.: New empirical relationships among magnitude, rupture length, rupture width, rupture area, and surface displacement, B. Seismol. Soc. Am., 84(4), 9741002, 1994.

Youd, T. L., Idriss, I. M., Andrus, R. D., Arango, I., Castro, G., Chrstian, J. T., Dobry, R., Finn, W. D. L., Harder Jr., L. F., Hynes, M. E., Ishihara, K., Koester, J. P., Liao, S. S., Marcuson, W. F., Martin, G. R., Mitchell, J. K., Moriwaki, Y., Power, M. S., Robertson, P. K., Seed, R. B., and Stokoe, K. H.: Liquefaction resistance of soils, Summary report from the 1996 NCEER and 1998, NCEER/NSF workshop on evaluation of liquefaction resistance of soils, J. Geotech. Geoenviron. Eng.-ASCE 127(10), 817-833, 2001.

Yuan, H., Yang, S. H., Andrus, R. D., and Juang, H.: Liquefaction induced ground failure: A study of the Chi Chi earthquake cases, Eng. Geol., 17(1-2), 141-155, doi:10.1016/S00137952(03)00130-3, 2003. 